\title{
Enhancing Success at University: Understanding our Students Through Their Learning Careers
}

\author{
Felicity Reid \\ Auckland University of Technology, New Zealand \\ Janis Davidson \\ University of Glasgow, United Kingdom
}

\begin{abstract}
This article discusses a study that started from the premise that we can better support our students when we know who they are. The study used narrative analysis to explore reasons for success for undergraduate business students in a New Zealand university. Drawing on the work of Bourdieu and the concept of learning careers (Bloomer \& Hodkinson, 2000 ) the study gained insights into the students' educational journeys, the development of an educated habitus (Nash, 2002) and the importance of the development of social, academic and emotional capital on the journey towards success. The study reinforced findings about the non-linear paths to and through university of some students, and the importance of parental emotional support in student success. It demonstrated the usefulness of the concept of learning careers to better understand who our students are, and consequently how to better support them to succeed.
\end{abstract}

Keywords: Bourdieu; learning careers; habitus; student success; narrative analysis; emotional capital.

\section{Introduction}

Universities are constantly looking for ways to better support their students to succeed. There is now a significant amount of literature which seeks to identify factors that influence students' success or withdrawal from university (see van der Zanden et al., 2018; Harvey et al., 2006 for literature reviews). A more holistic way to gain insights into how better to support students to succeed is to get to know who our students are. The focus of our discussion is part of a study that used the concept of learning careers as a framework to examine students' educational and life experiences in order to gain insights into why they were succeeding at university. A narrative approach was taken and the experiences were analysed by drawing on the work of Bourdieu. The study found that using a framework of learning careers was useful and that students' experiences in the past, as well as their experiences while they were at university could have some relevance in explaining their success. Tracing the students' educational journey suggested that the development of confidence and academic capital (Naidoo, 2004) is influential for success; that social capital (Bourdieu, 1986) in the form of peer support is also important. It also found that although the non-traditional students in the study came from families that were not familiar with the education system, the provision of emotional capital can be an important factor in their success. This supports the argument by Reay (2000) that parental support for university studies can create emotional capital and help students succeed.

The article begins with a review of student success literature and an outline of the concept of learning careers. Then the research is described, including details of the participants. Finally, the findings of the study are discussed and implications for university practice to support student success are identified.

Except where otherwise noted, content in this journal is licensed under a Creative Commons Attribution 4.0 International Licence. As an open access journal, articles are free to use with proper attribution. ISSN: 2205-0795 


\section{Literature}

The quest to understand what supports student retention and success in higher education has been largely dominated by models of social and academic integration (Harvey et al., 2006) which was the model first developed by Tinto (1993). Further studies attempted to identify factors which individually or collectively either contributed to student success or encouraged early withdrawal from university. These included incompatibility between student and institution, inadequate preparation for university, financial issues, limited commitment and academic progress (Yorke, 1999), personal reasons, wrong choice of course, lack of integration and dissatisfaction with the institution (Davies \& Elias, 2002; National Audit Office, 2007; Yorke \& Longden, 2008). The role of engaging students in their learning through orientation, curriculum and classroom practices that recognise student diversity, student centred learning, study skills and feedback has also been emphasised (Crosling et al., 2009). As widening participation has continued, studies have identified the importance of the role of social integration and a sense of belonging (Thomas, 2012; Thomas \& Hanson, 2014) as well as institutional commitment to the student experience and recognising students as individuals (Yorke \& Thomas, 2003).

Subsequent to identification of individual factors supporting success or otherwise it has been argued that withdrawal cannot be attributed to one variable but is instead the result of combinations of student characteristics, external factors and institution related issues (Harvey et al., 2006). Studies seeking to identify individual factors in student success or withdrawal have been supplemented with studies taking a more sociological approach (Harvey et al., 2006). This includes drawing on the work of Bourdieu as a means of countering the dominant policy view of individual responsibility, through recognition of the role of structure as well as agency (Warren \& Webb, 2007).

In order to explain social practices and to gain insights into the complexity of the social world Bourdieu developed a set of thinking tools (Grenfell, 2012) in which the resources possessed by the dominant classes were referred to as forms of capital (economic, cultural, social and symbolic) (Bourdieu, 1986). The relationship of these forms of capital with habitus, which is the set of dispositions acquired by a person through their life experience (Bourdieu \& Wacquant, 1992), and the field which is the social space within which interactions occur in which the person finds themselves (Thomson, 2012), was used by Bourdieu to explain the practice of people (Reay, 2004).

Bloomer and Hodkinson (2000) drew on the work of Bourdieu as well as symbolic interactionism to develop the concept of learning careers. This was intended as a tentative theoretical framework which recognised that learner pathways are not linear but that students' dispositions to learning change over time and that we need to take into account the experiences of the student both within the educational sphere and outside it, and how those experiences relate to a person's learning. A key feature of learning careers, which clearly shows the influence of Bourdieu's concept of habitus, is a temporal focus - that is, the consideration of a student's changes in disposition to learning over time, as well as consideration of current experiences outside university. Bloomer (2001) said that any theory of learning must have "lateral and temporal connectivity" (2001, p.429) continuing:

That is to say, it must be informed by an understanding, firstly, of how learning connects (laterally) with context and with the life experiences of the learner(s) concerned and, secondly, how one set of learning experiences connects (temporally) with others that precede or follow it. (p.429)

This feature distinguishes the approach from much of the literature about students' success which focuses on students' situations and experiences while at university.

In New Zealand where the study that is the subject of this article took place, Bourdieu's concepts underpinned a call by Zepke and Leach for institutions to take steps to adapt to students rather than requiring students to assimilate into the institution (Zepke \& Leach, 2005; Zepke \& Leach, 2007; Zepke, Leach, \& Prebble, 2005). Other studies recognise the importance of fit between the student and the institution through recognition of cultural identity and culturally supportive practices to support student success (Benseman et al., 2006; Curtis \& Townsend, 2012; Curtis et al., 2015; Earle, 2008; Gavala \& Flett, 2005). However, while some New Zealand literature recognises the importance of the student being comfortable with the institution, which alludes to Bourdieu's concept of habitus, there have been few empirical studies in New Zealand higher education that apply Bourdieu's toolkit or the concept of learning careers as a framework to analyse student success. In particular, there are few studies that consider the contribution of students' experiences prior to university as a means of providing insight into why they succeed at university. The study that is reported here attempted to address that gap by using learning careers as a 
framework drawing on Bourdieu's toolkit to explore students' narratives and make connections between their contexts and experiences and their success at university.

\section{The Study}

The research was undertaken as part of a doctorate (Reid, 2018) and focused on successful students in an undergraduate Business degree in New Zealand. There was a focus on exploring how the students' backgrounds and prior life and educational experiences contributed to success at university, and how their contexts and experiences while at university also contributed to that success. This was driven by a desire to gain a better understanding of our students so that in turn, we could have a better understanding of how to support them. Ethics approval was obtained from both the institution supervising the study and the institution where the students were studying.

"Success" for the purposes of recruitment of participants was defined as having successfully completed sufficient compulsory first semester courses to enable progression to at least semester two of their six semester undergraduate degree. Purposive sampling was used to recruit students who were at least in their second semester of degree study, and who had been through the New Zealand school system - a pool of approximately 2300 students. Approximately 1000 invitations were distributed by academic colleagues in lectures that were chosen for their large numbers and were compulsory courses in a range of majors, until ten students who met the criteria had responded. These students came from a range of ethnicities and backgrounds. They ranged from being in their second semester of study to being in their final year and were undertaking a variety of business majors. Data were gathered from semi-structured interviews of between one and two hours in which the students talked about their educational experiences and their family context. Loosely structured prompts such as "tell me about your family; "tell me about your primary school years"; "tell me about secondary school" were used. These were designed to keep the interview length manageable and focused without limiting what the students chose to include or leave out in their narratives. Table 1 provides details of the participants (using pseudonyms). 
Table 1

Participant Details

\begin{tabular}{|c|c|c|c|c|c|c|c|}
\hline Student & Age & Ethnicity & $\begin{array}{c}\text { School } \\
\text { Decile * }\end{array}$ & Family education & $\begin{array}{c}\text { Mother's } \\
\text { occupation }\end{array}$ & $\begin{array}{c}\text { Father's } \\
\text { occupation }\end{array}$ & $\begin{array}{c}\text { Year } \\
\text { of } \\
\text { degree }\end{array}$ \\
\hline Aaron & 22 & Tongan & 4 then 3 & $\begin{array}{l}\text { Father - polytechnic } \\
\text { qualification } \\
\text { Mother - polytechnic } \\
\text { qualification } \\
\text { Sister already at university }\end{array}$ & Healthcare worker & $\begin{array}{l}\text { Automotive } \\
\text { engineer - small } \\
\text { business owner }\end{array}$ & $1^{\text {st }}$ year \\
\hline Daniel & 21 & $\begin{array}{l}\mathrm{NZ} \\
\text { European }\end{array}$ & 7 & $\begin{array}{l}\text { Father - secondary school } \\
\text { Mother -secondary school }\end{array}$ & $\begin{array}{l}\text { Sickness } \\
\text { beneficiary }\end{array}$ & $\begin{array}{l}\text { Bricklayer }- \text { small } \\
\text { business owner }\end{array}$ & $1^{\text {st }}$ year \\
\hline Dinah & 19 & Samoan & 8 & $\begin{array}{l}\text { Father - secondary school } \\
\text { (Samoa) } \\
\text { Mother - secondary school } \\
\text { (Samoa) } \\
\text { Sister already at university }\end{array}$ & Receptionist & Supervisor & $1^{\text {st }}$ year \\
\hline Emma & 22 & $\begin{array}{l}\text { Maori/NZ } \\
\text { European }\end{array}$ & 4 & $\begin{array}{l}\text { Father - secondary school } \\
\text { Mother - polytechnic } \\
\text { qualification (nursing) }\end{array}$ & Medical sales & $\begin{array}{l}\text { Small business } \\
\text { owner }\end{array}$ & $3^{\text {rd }}$ year \\
\hline Eva & 22 & Samoan & 2 & $\begin{array}{l}\text { Father - teaching } \\
\text { qualification (Samoa) } \\
\text { Mother - secondary school } \\
\text { (Samoa) }\end{array}$ & $\begin{array}{l}\text { Stay at home } \\
\text { mother }\end{array}$ & $\begin{array}{l}\text { Furniture } \\
\text { manufacturing } \\
\text { employee }\end{array}$ & $2^{\text {nd }}$ year \\
\hline Lily & 25 & Thai & 4 & $\begin{array}{l}\text { Father - secondary school } \\
\text { (Thailand) } \\
\text { Mother - primary school } \\
\text { (Thailand) } \\
\text { Half-sister already at } \\
\text { polytechnic }\end{array}$ & $\begin{array}{l}\text { Machinist in } \\
\text { sewing factory } \\
\text { (Thailand) }\end{array}$ & $\begin{array}{l}\text { Plasterer - self } \\
\text { employed }\end{array}$ & $2^{\text {nd }}$ year \\
\hline Nadia & 21 & $\begin{array}{l}\text { North } \\
\text { African }\end{array}$ & 4 & $\begin{array}{l}\text { Father - undergraduate } \\
\text { degree (North Africa) } \\
\text { Began postgraduate } \\
\text { certificate (NZ) } \\
\text { Mother - no schooling } \\
\text { Two older sisters } \\
\text { undertaking postgraduate } \\
\text { study }\end{array}$ & $\begin{array}{l}\text { Stay at home } \\
\text { mother - assist in } \\
\text { family business }\end{array}$ & $\begin{array}{l}\text { Small business } \\
\text { owner }\end{array}$ & $1^{\text {st }}$ year \\
\hline Sam & 21 & Tongan & 8 & $\begin{array}{l}\text { Step-father - Secondary } \\
\text { school } \\
\text { Mother - University } \\
\text { Nursing qualification } \\
\text { Older brother already at } \\
\text { university }\end{array}$ & Nurse Manager & Truck driver & $3^{\text {rd }}$ year \\
\hline Tom & 20 & $\begin{array}{l}\mathrm{NZ} \\
\text { European }\end{array}$ & 8 & $\begin{array}{l}\text { Father - secondary school } \\
\text { Mother - secondary school }\end{array}$ & Administration role & $\begin{array}{l}\text { Bricklayer }- \text { small } \\
\text { business owner }\end{array}$ & $3^{\text {rd }}$ year \\
\hline Zoe & 19 & $\begin{array}{l}\text { Maori/NZ } \\
\text { European }\end{array}$ & 10 & $\begin{array}{l}\text { Father - undergraduate } \\
\text { degree } \\
\text { Mother - teaching } \\
\text { qualification (Teacher's } \\
\text { college) }\end{array}$ & Teacher & $\begin{array}{l}\text { CEO of a not -for- } \\
\text { profit organisation }\end{array}$ & $2^{\text {nd }}$ year \\
\hline
\end{tabular}

Notes: School decile is a socio-economic measure used by the Ministry of Education in New Zealand. While it is only a proxy it roughly equates to decile 1 schools being in the lowest socio-economic areas through to decile 10 schools being the highest socio-economic areas 
The study data were analysed using narrative analysis which involves collecting events or happenings and configuring them into a plot for each participant (Polkinghorne, 1995) - a process commonly known as "restorying" (Creswell \& Poth, 2018). Polkinghorne (1988) argued that the process of developing narratives into a plot is a form of analysis because it requires the researcher to make connections between events. Polkinghorne's narrative analysis fitted well with the nature of learning careers which require an understanding both of students' experiences while at university but also their prior experiences and how these have influenced dispositions to learning. A narrative approach has also been recognised as enabling students to critically reflect on their learning journey and to better understand themselves (Benson et al., 2010) and indeed several students commented at the end of the interviews that they had found it to be a sense making process.

The data in this study were analysed into a story for each individual student. Inductive open coding of the data and thematic analysis (Braun \& Clark, 2006) were used to identify commonalities across the stories. A second phase of analysis of the data was undertaken through a Bourdieusian lens. This involved re-coding the transcripts drawing on the work of Merrill and West (2009) identifying forms of capital, the individual student's attitude or disposition in particular situations and interactions with structure. Commentaries for each participant were prepared addressing questions posed by Reay (1995) focusing on how the individual's experiences shaped their responses to situations. These questions included:

- How well adapted is the individual to the context they find themselves in?

- How does personal history shape their responses to the contemporary setting?

- What subjective views do they bring to the present and how are they manifested?

- Are structural effects visible within small scale interactions?

(Reay, 1995, p.369)

Further thematic analysis (Braun \& Clark, 2006) was undertaken on the commentaries after this individual analysis had been done - rather than thematic analysis across the raw data.

\section{Findings}

The students came from diverse backgrounds. Some students had one parent who had been to university, but most did not. Table 1 illustrates the diversity amongst the students in terms of ethnicity, socio-economic status and levels of parental education. Despite this diversity, the study revealed that the students had several things in common. These were: an ability to articulate the value their parents placed on education; a willingness to learn; confidence that they could learn; and an ability to articulate why they thought they were successful at university. This is consistent with Nash's (2002) concept of "educated habitus" which he suggested can be an explanation for success at school (p.1).

This finding went some way towards providing an explanation for the students' success at university. However, such a finding does not in itself help universities to better support students and we consider that the more useful part of the study was exploring how the students came to have an educated habitus. In this respect the framework of learning careers was particularly useful. We explored how the students came to develop an educated habitus by tracing the students' learning careers focusing particularly on the development of academic capital (a form of cultural capital [Naidoo, 2004]) and social capital during their learning careers, which in turn supported the development of an educated habitus.

\section{Learning Careers: The School Years}

Exploring the context and experience of the students began with the students' family backgrounds and their early educational experiences. The students in this study did not report significant parental involvement in their education and it was apparent from the narratives that at least some of the parents, particularly those who were immigrants, were not familiar with the New Zealand education system. However, common to all the students was a perception that at least one of their parents valued education and they were able to articulate how that value was conveyed to them as children:

They [Aaron's parents] have strong views on education. I guess that's [why] they came here as well. So they know education is key. It's a very powerful tool. [Aaron] 
Because my parents always tell us that "always do well at school because education is key". And they don't want us to end up like what they had like they didn't complete high school and so they wanted a different situation with us. [Dinah]

\section{Development of Academic Capital}

The students in the study (with the exception of Nadia who had no primary schooling) all had positive associations with their early schooling. The students' narratives suggested that it was later in their schooling experiences that their different experiences either reinforced their growing academic confidence or they experienced setbacks which dented their academic confidence. The students were able to articulate how they felt about learning as a result of positive events or negative setbacks. They talked of experiencing frustration, anger or feeling conflicted which turned to feeling encouraged, affirmed, positive and growing in confidence as they experienced success. The students' positive experiences at school included recognition in the form of awards (Dinah), recognition by a teacher that the student had potential and was advanced to a higher stream (Nadia, thereby setting her on a more positive learning journey from what she had experienced to date), and success at qualifications (Tom, Emma, Zoe). Eva described the positive affirmation she received after changing her attitude to school (initially out of fear of her father's anger):

And then the teacher starts to respond to you so like they start to benefit ... to reward you mostly. So then when that happens you're pushed out of that thinking like 'Oh I've got to do this for my Dad'. It was now a thought for you.

Experiences that impacted negatively on the students included coming to a new country and as a result of not speaking the language, going from being high achieving to not understanding (Lily and Eva); and failing school qualifications including not meeting the University Entrance (UE) ${ }^{1}$ requirements (Dinah, Aaron, Sam and Eva). These events resulted in a more negative attitude towards learning from that previously held. Lily recounted her feelings of frustration coming from being high achieving in her native Thailand to encountering the New Zealand school system with little English:

My gosh even [when] the teacher asked for the answer. I know it, I know it in Thai. How can I answer it in English. I couldn't express anything in English.

Tom, Sam, Emma, Daniel, Lily and Zoe had achieved at school early and consistently, while Aaron, Dinah and Eva had experienced setbacks and only achieved success later in their schooling years. The former students' narratives suggested that they had more academic confidence than the latter, whose academic confidence appeared to be more fragile. For example, Dinah, Eva, Aaron and Sam did not gain UE at the end of their schooling, but their response to that varied. Eva and Dinah reported having had a negative attitude to school early in their secondary schooling (which was at odds with their parental views about the importance of education) but had changed that attitude and achieved academic success later in their secondary schooling. Their academic confidence appeared to be more fragile, and they expressed that they felt devastated when they did not gain UE. In contrast to these two students, Sam's response was quite different. He was not first in family to university and appeared to have greater levels of academic confidence. He talked of success at school from an early age and attributed his failure to gain UE on being distracted by sport and peer groups. Whereas Eva and Dinah made quick decisions and embarked on foundation courses, Sam went back to his school to gain the missing credits in time to get into the first semester of university. This option was also open to Eva, but she did not appear to be aware of it, and she spent an additional year in higher education studies before she met the requirements to get into university.

When Aaron failed UE, he enrolled in a polytechnic course but failed that. He then went on a Mission for his church for two years in which time he said his view of education as being important was cemented and he gained confidence that he could still learn because he learned two languages while he was away:

When I learned the new language, I realised that gosh I can actually learn something new. Even though ... because I kind of thought well I'm old now so I can't really learn anything new but that's not true. Yeah just put your mind to it. It's a cliché but it's true - put your mind to it.

Nadia and Daniel gained UE and enrolled in a degree but did not enjoy it and withdrew. However, this did not appear to dent their academic confidence. Rather, it meant that their journey to success in the Business degree was not linear. Only Tom and

\footnotetext{
${ }^{1}$ University Entrance (UE) is the minimum requirement to go to a New Zealand university https://www.nzqa.govt.nz/qualificationsstandards/awards/university-entrance/
} 
Zoe began the Business degree straight out of school and were on track to complete within three years. The remaining students either had to undertake further study to gain entry (Aaron, Eva, Dinah), failed courses and had to repeat (Sam, Lily), or started university but changed degrees (Nadia, Daniel, Emma) - in Emma's case when she was almost at the end of her first choice of degree. This suggests that for the students in this study, while a solid level of achievement at school can build academic capital that supports success, failure to amass that capital in the school system is not the end of the matter. Life experiences or pre-degree study can help students to develop the academic capital necessary to succeed at university. In that respect the findings of the study support the New Zealand educational policy that any student who has attained the age of 20 years can enter into an open entry degree - that is a degree that only requires UE and does not have additional selection criteria.

\section{Learning Careers: The University Years}

\section{External Pressures}

Although at the time of the interviews all the students said they felt comfortable with the university environment, some students experienced challenges when they first arrived at university. Sam and Aaron said that they found the scale of university daunting and the lack of structure and freedom of time distracting. However, the remaining issues that students experienced all occurred outside the university. For example, both Dinah and Eva found it difficult living away from home for the first time. Both were staying with extended family. Dinah commented that the noise level where she lived was high and that her extended family did not understand that she needed quiet time, because none of them had been to university. As a result, she stayed at university to do all her study. Eva said that the level of conflict over money in the home she was staying at caused her to feel she needed to contribute more financially, but the hours she spent working impacted negatively on her performance at university. However, after seeking support from her parents she was able to sort out the issues with her extended family. She observed:

So I don't think it was the environment [at university] that failed me. It was what was going on at home. Which also taught me that ... everything that is around you all the time affects the way you ... school I guess. Affects the way you are educated.

\section{Social Capital in the Form of Peer and Family Support}

Just as all the students said their parents had articulated the importance of education, all the students said that their parents were supportive of them going to university. As well, almost all the students referred to the importance of peer support saying they were able to find like-minded friends who were keen to study:

I think just yeah surrounding myself with good people. I'm very grateful and very... very lucky that the teams I have been placed into are like-minded. Everyone's ambitious to graduate and to graduate well rather than just scraping by. [Aaron]

So um beside turning up to class all the time I think I took Dad's advice of surrounding yourself with the right people. [Eva]

These students had identified that mixing with people with similar academic aspirations was helpful and important to their own academic success.

\section{Discussion}

In several ways, the experiences of the students in this study reflected what Bloomer and Hodkinson (2000) identified about the experiences of non-traditional students. Most of the students' paths to and through higher education were not linear, either because they initially failed UE or they failed a course in their degree or changed degrees; some of their decision making was not always well informed - for example Dinah's and Eva's decision making about their options when they failed UE; they were influenced by their social group and their individual learning journeys were difficult to predict.

The exploration of the students' learning careers on their journey to developing an educated habitus provided insight into the lack of linearity, some of the reasons for that and the impact on the students' academic confidence. Confidence is a feature in Nash's (2002) concept of educated habitus and could be said to be part of a disposition to be academic, which along with academic performance, constitutes academic capital (Naidoo, 2004). Of note was that those students with greater academic confidence appeared to respond to setbacks differently from those whose confidence was more fragile, in that the latter were 
devastated but accepting, whereas the former sought to remedy the situation. In particular, Eva and Dinah who were the first generation in their family to go to university and had relatively newly acquired academic confidence, responded to their failure to gain UE differently from Sam who was more academically confident, had an extended family with university education and remedied the situation quickly. Dinah and Eva's response appeared to align with the argument by Byrom and Lightfoot (2013) that where a non-traditional student has accepted the messages about the value of education from home and school, and aligned their behaviour with those expectations, the experience of failure can be devastating.

The study also reinforced what Bloomer and Hodkinson (2000) identified in their concept of learning careers i.e., that what is going on in a student's life has a bearing on their disposition to learning. Eva's observation quoted earlier showed her making the connection between difficulties in home life and success at university. The students' acknowledgement of the value of social capital in the form of like-minded peers reflects an important aspect of fit with the institution (Dewart \& Rowan, 2007; Reay et al., 2010).

This study builds on Bloomer and Hodkinson's (2000) identification of experiences of non-traditional students. The students in this study placed value on education and this was something they attributed to their parents' articulation of this value. They acknowledged the emotional support their parents provided during their education, even if not all their parents were familiar with the education system. Levels of parental education and parental involvement in their children's education have been the subject of research in the United Kingdom that found that while middle class parents are adept at using their resources to make the most of opportunities in education (Ball, 2003), working class parents are less involved with their children's schooling than middle class parents (Reay, 2000). This is not necessarily because they do not want to be involved, but because they lack familiarity with the system or are not confident (Reay, 1997; Snee \& Devine, 2014). While the type of support that the students in this study said their parents provided was different from that identified by Ball's study of middle class parents (2003) such as navigating their child's journey to university, it was clearly support that the students identified as important to their educational success. This supports the argument of Reay (2000) that emotional support can encourage the development of capital that better equips students to succeed in higher education. Parental support for studying at university also minimises the likelihood of a student feeling they have to move between two worlds - the world of home and the world of university, which can result in the student distancing themselves from one or other world with a risk of changing relationships with friends and family (Lehmann, 2014).

What do these findings mean for universities? It seems fairly obvious to suggest that a student with an educated habitus - the confidence and willingness to learn - is more likely to succeed at university. This can be added to the list of factors that support student success at university. The more difficult issue is understanding how that educated habitus is developed and maintained. It would be unrealistic to suggest that universities could achieve such an in-depth understanding of all their students and their past and current experiences. However, by using a narrative approach to explore the learning careers of individual students, this study provided some insight into how dispositions to learning can be developed and maintained or de-railed.

Universities are not able to influence parental support or attitudes to education. However, with the knowledge of the importance of these factors, universities can support wider societal initiatives to foster these, and include such an awareness as part of a holistic approach to student advice. This may include providing a mentor to support a student where there is limited parental emotional support.

Like parental support, social capital in the form of peer support was also important to the students in the study. Being able to find other students with similar goals is a reflection of the institutional habitus of the university, in that there can sometimes be a disjuncture between the aspirations of the individual, who may want to study hard, and the culture of the institution which may be one of laid-back learners (Reay et al., 2010). A recognition of the role of like-minded peers in supporting students could be taken into account through student advising, ensuring first year classes provide opportunities for social connection and facilitating the establishment of study groups.

This study showed that the students with strong academic confidence developed over a sustained period reacted more positively and pro-actively to setbacks than the students with more recently developed and fragile academic confidence. Universities have no control over what occurs in schools which is where academic confidence can develop or be dented. Nevertheless, an awareness of the fragility of a student's academic confidence could be useful in providing advice and support 
for the student. As well, encouraging the provision of early constructive feedback for students new to university could be important to enhance learning and confidence (Hattie, 2008; Hattie \& Timperley, 2007).

The study also reinforced that while students' experiences inside and outside university are relevant, so too is what has gone on in the past. Understanding prior experience and context is helpful in identifying the extent to which there is alignment between the expectations of the higher education institution and the capital and habitus an individual student possesses. It should, however, be approached the other way around to illuminate how the institution can change to better align with the habitus and capital of its students. As Zepke and Leach (2005) have argued, universities should consider adapting more to their students rather than a default expectation that students assimilate into the institution in its current form. In practical terms, gaining an understanding of a student's background and current context may assist with academic advising, supporting their progression and triaging them to appropriate pastoral support. This is challenging with large numbers of students, but this study reinforced the importance of acknowledging students as individuals with unique experiences. The more administrative work of a routine nature that can be automated, the more student advisors would be freed up to work with students as individuals, so technology may have a significant part to play in supporting student success.

\section{Conclusion}

Although this study was small-scale, the narrative approach enabled rich data to be gathered and a deep analysis of individual learning careers of both traditional and non-traditional students to be undertaken. It provided insight into the individual experiences of students some of whom, by some measures, would not be considered successful. The journeys and challenges the students faced were illuminating. Further research into the experiences of students who did not continue at university, including their views of success, is needed to provide further insight into how best support students to get to and succeed at university. This study highlighted the individuality of students and reinforced some of the commonalities that can inform policy approaches on a wider scale, such as encouraging parental valuing of education and support for university study. Simple practical steps that universities can take, such as student advisors asking about support from home, where appropriate to do so; provision of student mentors to ensure ongoing support; ensuring there are opportunities for students to connect socially to foster a sense of belonging; facilitation of study groups to provide peer support and social interaction; and early constructive feedback on student work to help build confidence, would all be consistent with what helped the students in this study succeed. The study represented a microcosm of how these things can help support student success even in the face of challenges. It reinforced the relevance of the concept of learning careers which recognises that both what is going on currently in a student's life and what has gone on in the past are relevant to understanding success at university. 


\section{References}

Ball, S. (2003). Class strategies and the education market: The middle classes and social advantage. Routledge.

Benseman, J., Coxon, E., Anderson, H., \& Anae, M. (2006). Retaining non-traditional students: lessons learnt from Pasifika students in New Zealand. Higher Education Research \& Development, 25(2), 147-162. https://doi.org/10.1080/07294360600610388

Benson, R., Hewitt, L., Heagney, M., Devos, A., \& Crosling, G. (2010). Diverse pathways into higher education: Using students' stories to identify transformative experiences. Australian Journal of Adult Learning, 50(1), 26-54.

Bloomer, M. (2001). Young lives, learning and transformation: Some theoretical considerations. Oxford Review of Education, 27(3), 429-449. https://doi.org/10.1080/03054980120067456

Bloomer, M., \& Hodkinson, P. (2000). Learning careers: Continuity and change in young people's dispositions to learning. British Educational Research Journal, 26(5), 583-597. https://doi.org/10.1080/01411920020007805

Bourdieu, P. (1986). The forms of capital. In J. Richardson (ed.), Handbook of Theory and Research for the Sociology of Education (pp. 241-258). Greenwood.

Bourdieu, P., \& Wacquant, L. (1992). An invitation to reflexive sociology. Polity Press.

Braun, V., \& Clarke, V. (2006). Using thematic analysis in psychology. Qualitative Research in Psychology, 3(2), 77-101.

Byrom, T., \& Lightfoot, N. (2013). Interrupted trajectories: the impact of academic failure on the social mobility of working-class students. British Journal of Sociology of Education, 34(5-6), 812-828. https://doi.org/10.1080/01425692.2013.816042

Creswell, J., \& Poth, C. (2018). Qualitative Inquiry and Research Design: Choosing Among Five Approaches (4th ed.). Sage Publications Inc.

Crosling, G., Heagney, M., \& Thomas, L. (2009). Improving student retention in higher education: Improving teaching and learning. Australian Universities' Review, 51(1), 9-18.

Curtis, E., \& Townsend, S. (2012). Improving indigenous and ethnic minority student success in foundation health study. Teaching in Higher Education, 17(5), 589-602. https://doi.org/10.1080/13562517.2012.658559

Curtis, E., Wikaire, E., Kool, B., Honey, M., Kelly, F., Poole, P., Barrow, M., Airini, Ewen, S., \& Reid, P. (2015). What helps and hinders indigenous student success in higher education health programmes: A qualitative study using the Critical Incident Technique. Higher Education Research \& Development, 34(3), 486-500. https://doi.org/10.1080/07294360.2014.973378

Davies, R., \& Elias, P. (2002). Dropping out: A study of early leavers from higher education. http://www.dfes.gov.uk/research/data/uploadfiles/RB386.pdf

Dewart, B., \& Rowan, L. (2007). Improving tertiary student outcomes in the first year of study: What your students may not tell you. Journal of College Student Retention: Research, Theory and Practice, 9(3), 259-271. https://doi.org/10.2190/CS.9.3.a

Earle, D. (2008). Hei titiro an ō i te wh à inga: Maori achievement in bachelor's degrees revisited. Ministry of Education. https://www.educationcounts.govt.nz/publications/maori/english-medium-education/26451

Gavala, J. R., \& Flett, R. (2005). Influential factors moderating academic enjoyment / motivation and psychological wellbeing for Maori university students at Massey University. New Zealand Journal of Psychology, 34(1), 52-57.

Grenfell, M. (2012). Introduction. In M. Grenfell (Ed.), Pierre Bourdieu Key Concepts (2nd ed., pp. 1-6). Acumen.

Harvey, L., Drew, S., \& Smith, M. (2006). The first-year experience: a review of literature for the Higher Education Academy. https://www.qualityresearchinternational.com/Harvey\%20papers/Harvey\%20and\%20Drew\%202006.pdf

Hattie, J. (2008). Visible learning: A synthesis of over 800 meta-analyses relating to achievement. Routledge.

Hattie, J., \& Timperley, H. (2007). The power of feedback. Review of Educational Research, 77(1), 81-112. https://doi.org/10.3102/003465430298487

Lehmann, W. (2014). Habitus transformation and hidden injuries. Sociology of Education, 87(1), 1-15. https://doi.org/10.1177/0038040713498777

Merrill, B., \& West, L. (2009). Using biographical methods in social research. Sage Publications.

Naidoo, R. (2004). Fields and institutional strategy: Bourdieu on the relationship between higher education, inequality and society. British Journal of Sociology of Education, 25(4), 457-471. https://doi.org/10.1080/0142569042000236952

Nash, R. (2002). The educated habitus, progress at school, and real knowledge. Interchange, 33(1), 27-48. https://doi.org/10.1023/A:1016399826766

National Audit Office. (2007). Staying the course: The retention of students in higher education. Report by the Comptroller and Auditor General. http://www.nao.org.uk/pn/06-07/0607616.htm

Polkinghorne, D.E. (1988). Narrative knowing and the human sciences. State University of New York Press.

Polkinghorne, D. E. (1995). Narrative configuration in qualitative analysis. International Journal of Qualitative Studies in Education, 8(1), 5-23. https://doi.org/10.1080/0951839950080103

Reay, D. (1995). Using habitus to look at 'race'and class in primary school classrooms. In M. Griffiths \& B. Troyner (Eds.), Antiracism, culture and social justice in education (pp. 115-132). Trentham Books. 
Reay, D. (1997). Feminist theory, habitus, and social class: Disrupting notions of classlessness. Women's Studies International Forum, 20(2), 225-233. https://doi.org/10.1016/S0277-5395(97)00003-4

Reay, D. (2000). A useful extension of Bourdieu's conceptual framework? Emotional capital as a way of understanding mothers' involvement in children's schooling. Sociological Review, 48(4), 568-585. https://doi.org/10.1111\%2F1467954X.00233

Reay, D., Crozier, G., \& Clayton, J. (2010). 'Fitting in' or 'standing out': Working-class students in UK higher education. British Educational Research Journal, 36(1), 107-124. https://doi.org/10.1080/01411920902878925

Reid, F. (2018). Learning about student success from students' stories: A narrative study of successful business degree students at a New Zealand university [Doctoral Thesis, University of Liverpool].

Snee, H., \& Devine, F. (2014). Taking the next step: Class, resources and educational choice across the generations. Journal of Youth Studies, 17(8), 998-1013. https://doi.org/10.1080/13676261.2014.881987

Thomas, B., \& Hanson, J. (2014). Developing social integration to enhance student retention and success in higher education: The GROW@BU initiative. Widening Participation \& Lifelong Learning, 16(3), 58-70. https://doi.org/10.5456/WPLL.16.3.58

Thomas, L. (2012). What works? Facilitating an effective transition into higher education. Widening Participation and Lifelong Learning, 14, 4-25. https://doi.org/10.5456/WPLL.14.S.4

Thomson, P. (2012). Field. In M. Grenfell (Ed.), Pierre Bourdieu Key Concepts (2nd ed., pp. 65-80). Acumen.

Tinto, V. (1993). Leaving college: rethinking the causes and cures of student attrition: Live. University of Chicago Press.

van der Zanden, P. J. A. C., Denessen, E., Cillessen, A. H. N., \& Meijer, P. C. (2018). Domains and predictors of first-year student success: A systematic review. Educational Research Review, 23, 57-77.

https://doi.org/10.1016/j.edurev.2018.01.001

Warren, S., \& Webb, S. (2007). Challenging lifelong learning policy discourse: Where is structure in agency in narrativebased research? Studies in the Education of Adults, 39(1), 5-21. https://doi.org/10.1080/02660830.2007.11661537

Yorke, M. (1999). Leaving early: Undergraduate non-completion higher education. Falmer.

Yorke, M., \& Longden, B. (2008). The first-year experience of higher education in the UK. https://www.advancehe.ac.uk/knowledge-hub/first-year-experience-higher-education-uk-final-report

Yorke, M., \& Thomas, L. (2003). Improving the retention of students from lower socio-economic groups. Journal of Higher Education Policy and Management, 25(1), 63-74. https://doi.org/10.1080/13600800305737

Zepke, N., \& Leach, L. (2005). Integration and adaptation: Approaches to the student retention and achievement puzzle. Active Learning in Higher Education, 6(1), 46-59. https://doi.org/10.1177/1469787405049946

Zepke, N., \& Leach, L. (2007). Educational quality, institutional accountability and the retention discourse. Quality in Higher Education, 13(3), 237-248. https://doi.org/10.1080/13538320701800142

Zepke, N., Leach, L., \& Prebble, T. (2005). Now you've got them can you expect to keep them: Factors that influence student departure and persistence. New Zealand Journal of Educational Studies, 40(1 \& 2), 181-199.

Please cite this article as:

Reid, F., \& Davidson, J. (2022). Enhancing success at university: Understanding our students through their learning careers. Student Success, 13(1), 21-31. https://doi.org/10.5204/ssj.2013

This article has been peer reviewed and accepted for publication in Student Success. Please see the Editorial Policies under the 'About' section of the Journal website for further information.

Student Success: A journal exploring the experiences of students in tertiary education.

(c) (i) Except where otherwise noted, content in this journal is licensed under a Creative Commons Attribution 4.0 International Licence. As an open access journal, articles are free to use with proper attribution. ISSN: 2205-0795 